\title{
Topographic effects on crustal stress around the Atera Fault, central Japan
}

\author{
Koki Kumagai $^{{ }^{*}}$ and Takeshi Sagiya ${ }^{1,2}$
}

\begin{abstract}
The stress estimated from hydraulic fracturing test was inconsistent with a centroid moment tensor inversion result at the Atera fault area, Gifu Prefecture, central Japan. We demonstrate the stress obtained from a hydraulic fracturing mainly reflects topographic effect. We conduct a numeral computation of topographic stress using a formulation of the Boussinesq problem. The calculated maximum compression stress directions are consistent with the in situ measurement at the hydraulic fracturing depth. The results demonstrate the importance of topographic effects on crustal stress at a shallow depth.
\end{abstract}

Keywords: Atera fault, Boussinesq problem, Topographic stress, Hydraulic fracturing test

\section{Introduction}

The Atera fault is a 66-km-long active fault trending in the NW-SE direction and located in eastern Gifu Prefecture, central Japan (Fig. 1). Systematic offsets of river channels of about 7-10 km across the fault indicate a leftlateral motion (Sugimura and Matsuda 1965). Although the horizontal and vertical slip rates of the Atera Fault are estimated as $2-4 \mathrm{~mm} /$ year and $0.3 \mathrm{~mm} /$ year, respectively (Headquarters for Earthquake and Research Promotion 2004). The Atera fault is one of major active faults in the Japan mainland; present-day seismic activity of the Atera fault is low (Fig. 1). The stress field around the Atera Fault area estimated by the centroid moment tensor inversion is characterized by east-west compression favoring a left-lateral strike slip motion of the fault (Terakawa and Matsu'ura 2010), consistent with the geomorphologic features.

Yamashita et al. (2010) investigated the crustal stress condition around the Atera fault by means of hydraulic fracturing of boreholes. They reported that the maximum principal stress axes are oriented in the $\mathrm{N}-\mathrm{S}$ direction, favoring a right-lateral motion of the Atera fault. They also presented GPS velocity data to illustrate a

\footnotetext{
*Correspondence: bear@seis.nagoya-u.ac.jp

${ }^{1}$ Graduate School of Environmental Studies, Nagoya University, Furo-cho,

Chikusa-ku, Nagoya 464-8601, Japan

Full list of author information is available at the end of the article
}

right-lateral motion around the fault. Based on these observations, Yamashita et al. (2010) concluded that the Atera fault recently underwent a right-lateral motion. This conclusion contradicts the seismologically estimated stress field (Terakawa and Matsu'ura 2010) as well as long-term geologic features of the Atera fault. Therefore, their conclusion needs to be reconsidered carefully if there are other factors affecting the stress condition. As one of such possibilities, topographical effects in the crustal stress has been studied (e.g., Liu and Zoback 1992; Luttrell et al. 2011) and proven to be dominant at a shallow depth (Liu and Zoback 1992). Since the Atera fault is situated in a mountainous region with a complex topography, the topographical effects on the crustal stress are worth considering.

In this study, we demonstrate that the $\mathrm{N}-\mathrm{S}$ compressional stress obtained from a hydraulic fracturing mainly reflects a topographic effect. We conduct a numeral computation of topographic stress based on a formulation of the Boussinesq problem (Boussinesq 1885; Harding and Sneddon 1945). Our calculation shows that the topographic effect is effective in a shallow part of the crust, significantly changing the stress condition from the tectonic stress field. At the same time, the topographic effect is considered to be negligible at the seismogenic depth below a few kilometers. 


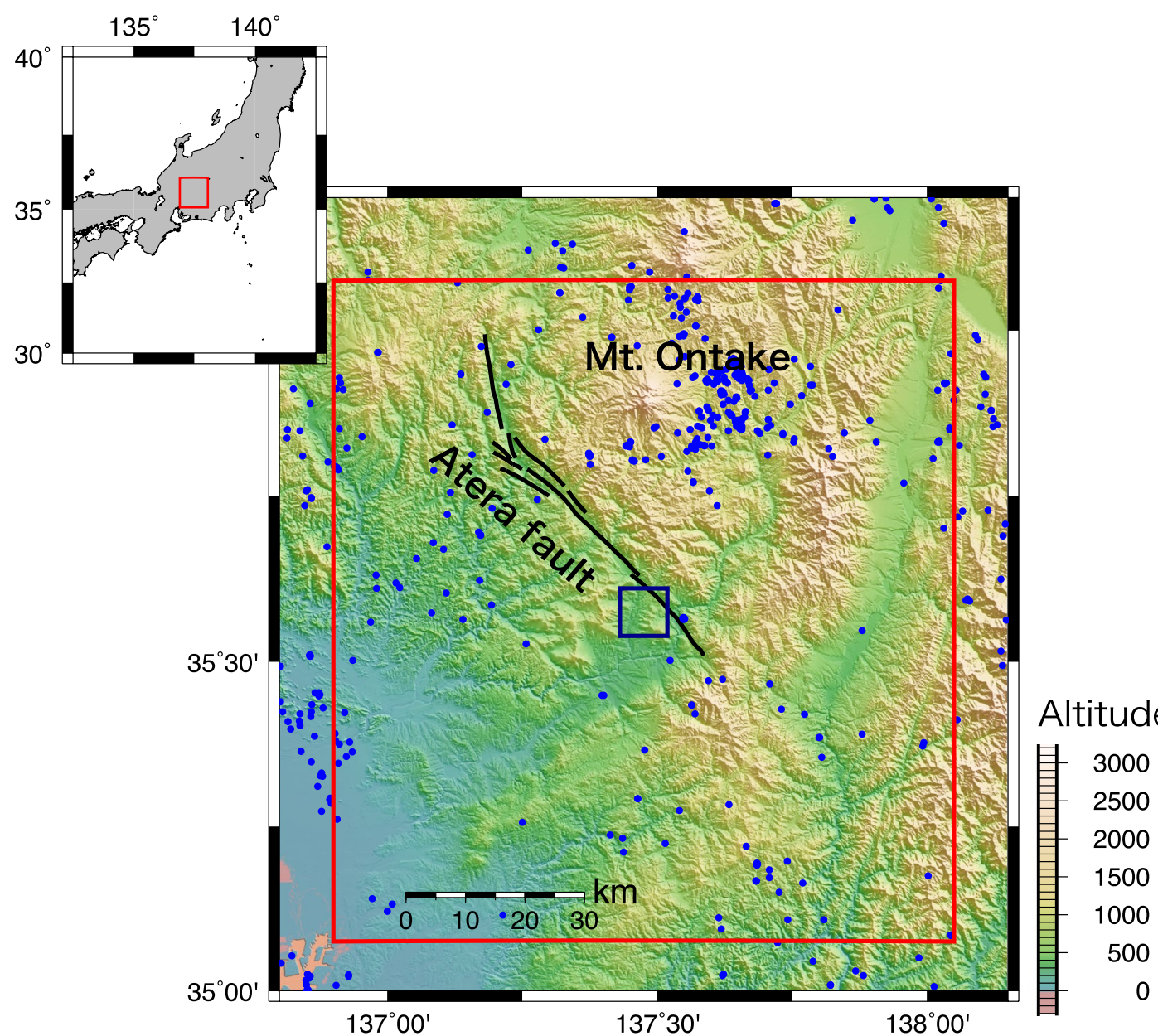

Fig. 1 The area of this study. Topography within the red square is taken into account for stress calculation. The small blue square is the area shown Fig. 2. The blue small circles denote shallow seismicity (2001-2010) with magnitude of $>1$ and a depth of $<20 \mathrm{~km}$ around the Atera Fault determined by Japan Meteorological Agency. The black lines denote the Atera Fault

\section{Method}

The Boussinesq problem deals with deformation of the elastic half-space $(z>0)$ due to a point load exerted at the surface. The $x$ and $y$ axes denote the north and east directions, respectively. Internal stress change at $(x, y, z)$ due to a point load $P$ at the origin is calculated by the following formulas (Boussinesq 1885; Harding and Sneddon 1945).

$$
\begin{aligned}
& \tau_{r r}=-\frac{P}{2 \pi R^{2}}\left\{-\frac{3 r^{2} z}{R^{3}}+(1-2 v) \frac{R}{R+z}\right\} \\
& \tau_{\theta \theta}=\frac{(1-2 v) P}{2 \pi R^{2}}\left(\frac{z}{R}-\frac{R}{R+z}\right) \\
& \tau_{r \theta}=0
\end{aligned}
$$

Here, $v$ is the Poisson's ratio, $R=\sqrt{x^{2}+y^{2}+z^{2}}$ is the distance between the stress calculation point and the load point, and $r=\sqrt{x^{2}+y^{2}}$ is the horizontal distance. In order to evaluate the stress condition and compare with the hydraulic fracturing result, we also take the lithostatic equilibrium into account, which is represented as $-\rho g z$ and added to all the normal stress components where $z$ is the calculation depth.

The elevation of the study area $\left(136.90^{\circ} \mathrm{E}-138.05^{\circ} \mathrm{E}\right.$, $35.075^{\circ} \mathrm{N}-36.075^{\circ} \mathrm{N}$, the red square, in Fig. 1) is $300 \mathrm{~m}$ or higher. The depth of the hydraulic fracturing test was equivalent to the altitude of about $60-190 \mathrm{~m}$. So we assume the altitude of $300 \mathrm{~m}$ as the reference plane and evaluate topographic stress assuming that the topographic load over the reference plane as point loads exerting on an elastic half-space with a regular grid interval of 
$50 \mathrm{~m}$. That is, the point load at the topographic height $H$ (in meter) is represented as follows.

$$
P=2500 \rho g(H-300)
$$

Here, $\rho$ is the crustal density $\left(\mathrm{kg} / \mathrm{m}^{3}\right)$ and $g$ is the gravitational acceleration $\left(=9.8 \mathrm{~m} / \mathrm{s}^{2}\right)$. If the altitude is lower than $300 \mathrm{~m}$, the load $P$ takes a negative value. We use a digital elevation map of $50 \mathrm{~m}$ mesh published by the Geospatial Information Authority of Japan for the calculation. Table 1 summarizes physical constants used for the calculation.

The area of stress evaluation is denoted as a smaller blue rectangle shown in Fig. 1. This rectangular area includes three sites for hydraulic fracturing by Yamashita et al. (2010). Within this area, the stress is evaluated at a horizontal regular grid with $200 \mathrm{~m}$ intervals. The vertical grid intervals are $100 \mathrm{~m}$ and $1,000 \mathrm{~m}$ above and below the depth of $1300 \mathrm{~m}$, respectively. We also evaluate the topographic stress at the in situ hydraulic fracturing sites by Yamashita et al. (2010). We calculate three horizontal stress components $\tau_{x x}, \tau_{y y}, \tau_{x y}$ and convert them

\section{Table 1 Physical constants for model calculation}

\begin{tabular}{lll}
\hline Density $\left(\mathbf{k g} / \mathbf{m}^{\mathbf{3}}\right)$ & Poisson's ratio & Gravitational acceleration $\left(\mathbf{m} / \mathbf{s}^{\mathbf{2}}\right)$ \\
\hline $2.7 \times 10^{3}$ & 0.25 & 9.8 \\
\hline
\end{tabular}

into principal stress axes as well as differential stress $\tau_{\text {diff }}=\tau_{H_{\max }}-\tau_{H_{\min }}$ at each calculation point.

\section{Results}

Figure 2 shows the calculated (lithostatic + topographical) crustal stress at the depth of $300 \mathrm{~m}$ corresponding to the mean sea level (MSL), $1.3 \mathrm{~km}$ (1 km below MSL), and $5.3 \mathrm{~km}$ ( $5 \mathrm{~km}$ below MSL). Three locations of the hydraulic fracturing by Yamashita et al. (2010) (UEN, FKO and HTJ) are denoted by blue circles. The calculated maximum compressional axes at the depth of $300 \mathrm{~m}$ are approximately in the $\mathrm{N}-\mathrm{S}$ direction at UEN and FKO while that at $\mathrm{HTJ}$ is in the $\mathrm{N} 33.5^{\circ} \mathrm{W}$ direction. It should be noted that even in a small area $(8 \mathrm{~km} \times 8 \mathrm{~km})$, stress orientation shows a significant rotation. This is mainly due to large topographic relief around this area. Table 2 compares calculated stress and the hydraulic fracturing results by Yamashita et al. (2010).

The calculated stress orientations are mostly concordant with the hydraulic fracturing measurements. On the other hand, the calculated stress values are less than the measurement by about $40 \%$ on average. We discuss a possible cause of the discrepancy later.

Calculated horizontal differential stress $\tau_{H_{\max }}-\tau_{H_{\min }}$ at UEN, FKO and HTJ are 3.2, 1.6 and 1.1 MPa, respectively. In general, calculated differential stress is larger near the Atera fault trace and gets smaller away from the fault (Fig. 2). Figure 3 shows the depth profile of differential stress at the 3 sites. Comparing with fault strength

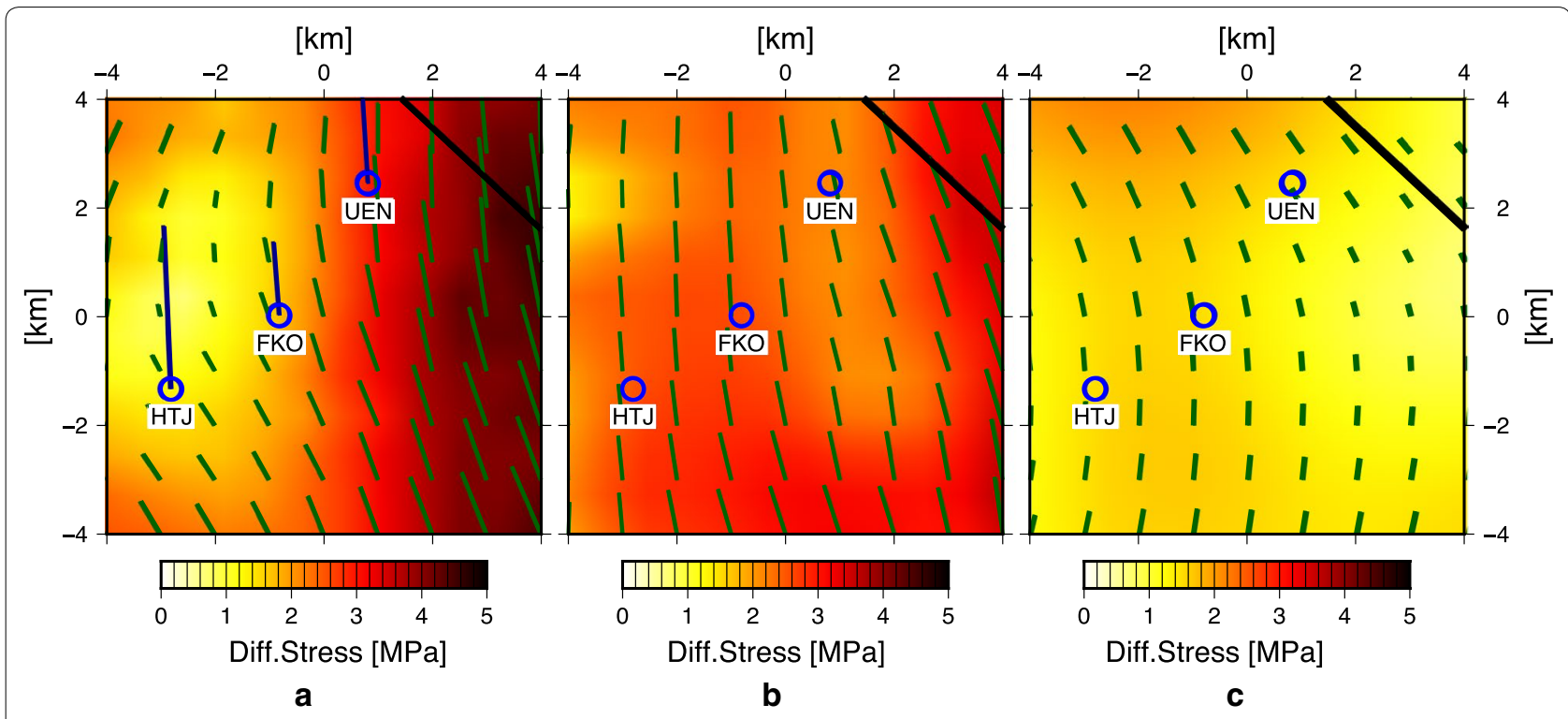

Fig. 2 Calculated differential stress and maximum compressional axis at the depth of a $300 \mathrm{~m}$ (at MSL), b $1.3 \mathrm{~km}$ ( $1 \mathrm{~km}$ below MSL), and c $5.3 \mathrm{~km}$ ( $5 \mathrm{~km}$ below MSL). The green lines indicate the magnitude of calculated differential stress and the direction of maximum compressional axis. The blue lines in (a) denote the Yamashita et al. (2010)'s result. The color indicates the magnitude of differential stress. The blue circles denote the locations of Yamashita et al. (2010)'s hydraulic fracturing test were carried out. The upper-right thick back line is the Atera fault trace 
Table 2 Calculation results at depth of HFT carried out and Yamashita et al.'s (2010) results

\begin{tabular}{|c|c|c|c|c|c|c|}
\hline & $\begin{array}{l}\text { Depth from ground } \\
\text { surface }(m)\end{array}$ & Altitude (m) & $\tau_{H_{\max }}(\mathrm{MPa})$ & $\tau_{H_{\text {min }}}(\mathrm{MPa})$ & Diff. (MPa) & $\Phi$ (deg.) \\
\hline \multicolumn{7}{|l|}{ UEN } \\
\hline HFT & 347 & 189 & 15.1 & 9.2 & 5.9 & N3.5W \\
\hline Calculation & & 189 & 8.8 & 5.6 & 3.2 & $\mathrm{~N} 1.2 \mathrm{~W}$ \\
\hline \multicolumn{7}{|l|}{ FKO } \\
\hline HFT & $243-276$ & $106-139$ & $12-16.2$ & $8.9-10.0$ & $2.9-6.2$ & $\mathrm{~N} 22.5 \mathrm{~W}-\mathrm{N} 17.3 \mathrm{E}$ \\
\hline Calculation & & 119 & 8.0 & 6.4 & 1.6 & N24.6W \\
\hline \multicolumn{7}{|l|}{ HTJ } \\
\hline HFT & $249-266.3$ & $61-78$ & $19.4-24.5$ & $11.8-14.2$ & $7.6-10.3$ & $\mathrm{~N} 20.5 \mathrm{~W}-\mathrm{N} 11.7 \mathrm{E}$ \\
\hline Calculation & & 70 & 9.0 & 7.9 & 1.1 & N36.5W \\
\hline
\end{tabular}

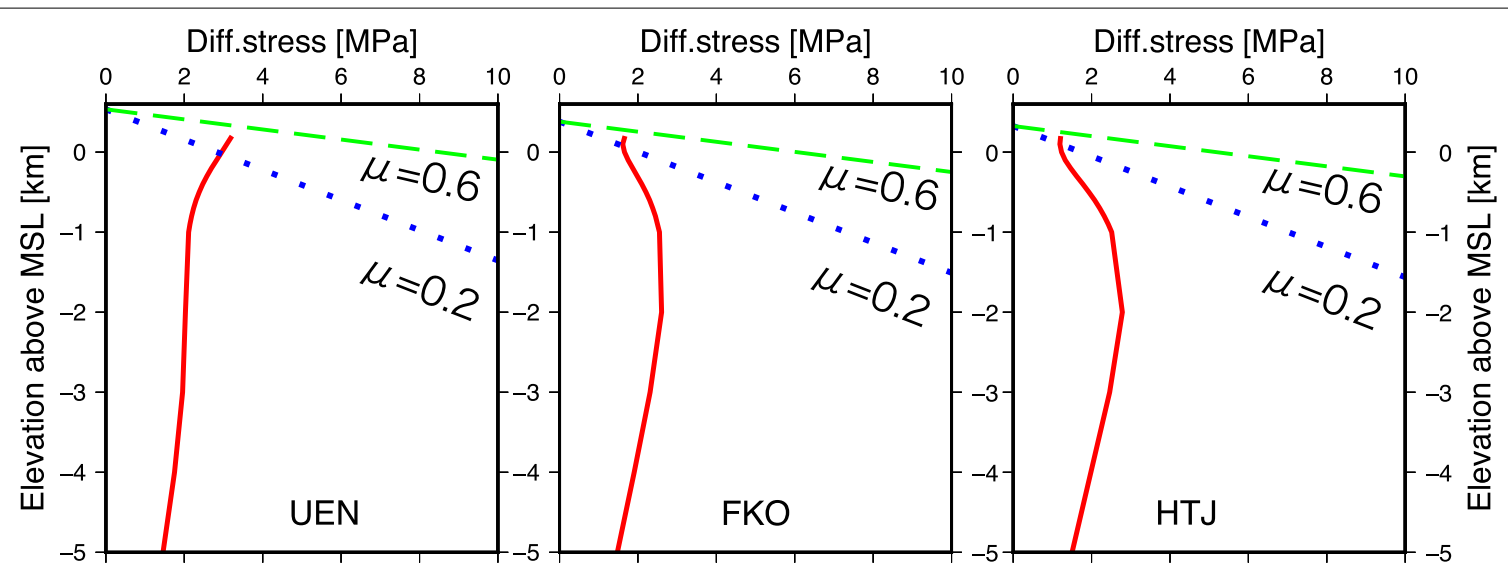

Fig. 3 Depth distribution of the calculated topographical differential stress and fault intensity. The red lines indicate depth distribution of the differential stress. The blue dotted and green dashed lines denote fault strength $(=\mu \rho g z)$ with a friction coefficient $\mu=0.2$ and 0.6 , respectively

profiles with frictional coefficients of 0.6 and 0.2 , the topographic stress is significant only in a shallow part less than $1 \mathrm{~km}$ from the ground surface. At the seismogenic depth of over $5 \mathrm{~km}$, differential stress caused by the topographic effect is negligible compared with the fault strength.

\section{Discussion}

Our calculation of topographic stress is consistent with the hydraulic fracturing results in their orientation, but the calculated stress value is smaller by about $40 \%$. It is rather a common characteristic for in situ stress measurement at a shallow (less than $1 \mathrm{~km}$ ) depth that the measured horizontal stress is much larger than the lithostatic stress (Brown and Hoek 1978; Sano 2005). According to Sano (2005), such a large horizontal stress can be explained by stress redistribution due to surface erosion (Goodman 1980) or self-gravitation of aspherical shell (McCutchen 1982). So it may not be appropriate to ascribe the measured stress pattern to a single cause like faulting or topography. However, the good correspondence between the observed and calculated stress orientations suggests the topographic effect is considered to be the major controlling factor for the measured stress around the Atera fault at a shallow depth.

Recent dense GNSS observation shows there is no significant differential motion across the Atera fault (Kumagai et al. 2017). Thus, the Atera fault is considered to be locked at least at its shallow portion and tectonic stress build-up is ongoing. Then, we need to consider a possible effect on such tectonic loading of the stress condition on the Atera fault and its surrounding. We evaluated tectonic stress change associated with the interseismic deformation of the Atera fault using a simplified elastic dislocation model by Savage and Burford (1973). If we assume an infinitely long vertical strike slip fault with a locking depth $D$ and slip a rate $V$ runs in the $y$ direction, the interseismic shear strain rate at the ground surface is described as follows.

$$
\dot{e}_{x y}=\frac{V}{2 \pi} \frac{D}{x^{2}+D^{2}}
$$


If we assume $D=15 \mathrm{~km}$ and $V=3 \mathrm{~mm} / \mathrm{yr}$ based on the regional seismogenic depth and geological studies (Headquarters for Earthquake Research Promotion 2004), the estimated shear strain rates at three sites (UEN, FKO and HTJ) are about $3 \times 10^{-8} \mathrm{yr}^{-1}$. Since the last earthquake of the Atera fault is considered to have occurred about 400 years ago (Hirouchi and Yasue 2011), the tectonic left-lateral shear stress on the Atera fault accumulated during 400 years is expected to be around $0.7 \mathrm{MPa}$, if we assume the crustal shear modulus to be $30 \mathrm{GPa}$. Therefore, if the last earthquake about 400 years ago completely released the tectonic stress, the topographic stress is considered to be still significant over the tectonic stress at a shallow depth less than a few $\mathrm{km}$, supporting our interpretation about the hydraulic fracturing result.

Our calculation suggests that Yamashita et al's (2010) in situ stress measurements mainly reflect a topographic effect. It should be noted that the Atera fault is situated at a special topographic feature so that stress condition can be largely perturbed. The Atera fault is running along a topographic boundary where a large altitude difference of about $800 \mathrm{~m}$ exists (Fig. 1). Since the topographic stress is proportional to the topographic load, an altitude contrast less than a few hundred meters does not affect the stress condition so much. On the other hand, at a greater depth, the topographic stress perturbation becomes smaller compared with the regional tectonic stress because of the elastic stiffness of the crust (Fig. 3). The maximum principal stress axes around the Atera fault are in the E-W direction at the depth of $10 \mathrm{~km}$ based on the moment tensor inversion (Terakawa and Matsu'ura 2010). So our result is consistent with the seismologically estimated regional stress field, which is also consistent with the long-term activity of the Atera fault, that is, the left-lateral strike slip motion based on geological and geomorphological evidence.

Another evidence of Yamashita et al. (2010) to support right-lateral motion of the Atera fault was the GPS observation data showing a right-lateral movement across the Atera fault. But this observation captures only the shortterm surface velocities, which should be strictly distinguished from the absolute strain or stress. Actually, the current study area is not free from elastic deformation due to interplate coupling at the Suruga-Nankai Trough where the Philippine Sea plate is subducting beneath southwest Japan. One supporting evidence of this inference is crustal deformation associated with the Tokai slow slip event during 2000-2005 (e.g., Ozawa et al. 2002; Miyazaki et al. 2006). We can identify southeastward displacement of the southwest part of the Atera fault that releases left-lateral shear strain across the fault. During the interseismic time period at the Suruga-Nankai Trough, right-lateral shear strain accumulation is expected. Such elastic strain should be released when a large earthquake occurs at the Suruga-Nankai Trough and does not accumulate over a longer time scale.

\section{Conclusion}

We evaluate the topographic perturbation on the crustal stress around the Atera fault using the Boussinesq problem with actual topographic information. The calculation suggests that the topographic effect is significant at a shallow depth and greatly affect the crustal stress pattern. The calculated maximum compressional axes at the hydraulic fracturing sites are directed in the $\mathrm{N}-\mathrm{S}$ direction, consistent with the observation. The results demonstrate importance of topographic effects on crustal stress at a shallow depth. The Atera fault is subject to E-W compressional stress, consistent with its geologically identified left-lateral motion.

\section{Author's contributions \\ KK conducted the numerical calculation and drafted the manuscript. TS super- vised KK, conceived of the study and helped to draft the manuscripts. Both authors read and approved the final manuscript. \\ Author details \\ ${ }^{1}$ Graduate School of Environmental Studies, Nagoya University, Furo-cho, Chikusa-ku, Nagoya 464-8601, Japan. ${ }^{2}$ Disaster Mitigation Research Center, Nagoya University, Furo-cho, Chikusa-ku, Nagoya 464-8601, Japan.}

\section{Acknowledgements}

We used topographic data published by the Geospatial Information Authority of Japan. Earthquake catalogue data were published by Japan Meteorological Agency. The manuscript was improved by comments from two anonymous reviewers.

\section{Competing interests}

The authors declare that they have no competing interests.

\section{Availability of data materials}

The computation code for topographic stress and the calculation result can be provided on request.

\section{Funding}

This work was supported by the Japan Society for the Promotion of Science (JSPS) KAKENHI Grant Numbers JP25350427 and JP26109003.

\section{Publisher's Note}

Springer Nature remains neutral with regard to jurisdictional claims in published maps and institutional affiliations.

Received: 30 August 2018 Accepted: 21 November 2018

Published online: 28 November 2018

\section{References \\ Boussinesq J (1885) Applications des potentiels a l'etude de l'équilibre et du mouvement des solides élastiques. Gauthier-Villars, Paris \\ Brown ET, Hoek E (1978) Trends in relationships between measured in situ stresses and depth. J Rock Mech Min Sci Geomech Abstr 15:211-215 Goodman RE (1980) Introduction to rock mechanics. Wiley, New York, pp $101-115$ \\ Harding JW, Sneddon IN (1945) The elastic stresses produced by the indenta- tion of the plane surface of a semi-infinite elastic solid by a rigid punch.}


Math Proc Camb Philos Soc 41(1):16-26. https://doi.org/10.1017/S0305 004100022325

Headquarters for Earthquake Research Promotion (2004) Evaluation of the Atera fault zone. https://www.jishin.go.jp/main/chousa/04dec_atera/ index.htm. Accessed 8 Nov 2018 (in Japanese)

Hirouchi D, Yasue K (2011) Latest faulting event of the Atera fault zone and the 1586 Tensho earthquake. Active Fault Res 35:51-56. https://doi. org/10.11462/afr.2011.35_1 (in Japanese with English abstract)

Kumagai K, Sagiya T, Matsuta N (2017) Tectonic loading of the Atera fault inferred from dense GNSS observation. The 128th meeting of the Geodetic Society of Japan, Mizunami, Japan, Oct 6, 2017

Liu L, Zoback MD (1992) The effect of topography on the state of stress in the crust: application to the site of the Cajon Pass Scientific Drilling Project. J Geophys Res 97(B4):5095-5108

Luttrell KM, Tong X, Sandwell DT, Brooks BA, Bevis MG (2011) Estimates of stress drop and crustal tectonic stress from the 27 February 2010 Maule, Chile, earthquake: implications for fault strength. J Geophys Res 116(B11):1. https://doi.org/10.1029/2011jb008509

McCutchen WR (1982) Some elements of a theory for in situ stress. Int J Rock Mech Min Sci Geomech Abstr 19:201-203

Miyazaki S, Segall P, McGuire JJ, Kato T, Hatanaka Y (2006) Spatial and temporal evolution of stress and slip rate during the 2000 Tokai slow earthquake. J Geophys Res. https://doi.org/10.1029/2004jb003426
Ozawa S, Murakami M, Kaidzu M, Tada T, Sagiya T, Hatanaka Y, Yarai H, Nishimura T (2002) Detection and monitoring of ongoing aseismic slip in the Tokai Region, Central Japan. Science 298:1009-1012

Sano O (2005) Measurement methods of contemporary stress filed and rock mechanics. J Geogr 114(6):1003-1021 (in Japanese with English abstract)

Savage JC, Burford RO (1973) Geodetic determination of relative plate motion in central California. J Geophys Res 78:832-845

Sugimura A, Matsuda T (1965) Atera fault and its displacement vectors. Geol Soc Am Bull 76:509-522

Terakawa T, Matsu'ura M (2010) The 3-D tectonic stress fields in and around Japan inverted from centroid moment tensor data of seismic events. Tectonics. https://doi.org/10.1029/2009tc002626

Yamashita F, Mizoguchi K, Fukuyama E, Omura K (2010) Reexamination of the present stress state of the Atera fault system, central Japan, based on the calibrated crustal stress data of hydraulic fracturing tests obtained by measuring the tensile strength of rocks. J Geophys Res. https://doi. org/10.1029/2009jb006287

\section{Submit your manuscript to a SpringerOpen ${ }^{\odot}$ journal and benefit from:}

- Convenient online submission

- Rigorous peer review

- Open access: articles freely available online

- High visibility within the field

- Retaining the copyright to your article

Submit your next manuscript at $\mathbf{s p r i n g e r o p e n . c o m ~}$ 